they use a lot of improper words, tautology. The development of lexical competence is considered as a step-by-step mastering of lexical concepts in the language system, maturity of lexical skills, ability to use them when speaking. The following methods of teaching lexical units are suggested: explanation, heuristic conversation, language observation, work with a textbook; as well as interactive, gaming and practical tasks. A fragment of a lesson has been suggested in the paper using didactic games, for example, "Ukrainian Chaplet". The experience of working at primary school has made it possible to emphasize the following lexical and semantic exercises contributing to the formation of children's national consciousness: listening comprehension of texts about Ukraine, exercise "Enriching one's vocabulary", "Speak oratorically", working with texts, interactive communicative exercises, etc. A teacher can also use such methods of enriching children's vocabulary: interpretation of a lexical meaning of a word by means of a dictionary; finding lexical and grammatical meaning of a word; making sentences using key words, finding synonyms, antonyms, text revision. One of the main tasks of a teacher is to prevent lexical mistakes in written and oral language of primary school students. The teaching methods and exercises will help to form primary school students' communication skills and contribute to the development of their speaking.

Keywords: language competence, lexical competence, vocabulary, teaching methods, exercises.

Подано до редакиії 09.02.2017

Рецензент: д. пед. н., проф. Г. В. Товканеичь

UDC: $376.1: 316.472 .3$

DOI: https://doi.org/10.24195/2414-4665-2017-2-9

Tamila Kolomoiets, PhD (Candidate of Sociological Sciences), senior lecturer, Kryvyi Rih State Pedagogical University, 54, Haharina avenue, Kryvyi Rih, Ukraine

\title{
SOCIALIZATION MODEL OF PRESCHOOLERS WITH SPECIAL NEEDS IN THE SYSTEM OF SPECIAL EDUCATION
}

Modern social relations in our country are far from being harmonious. As to educational system, such disharmony is even stronger because it is expressed in separating of mass and correctional education. Attempts to form inclusive education have not come to any considerable results, which appears in constant division of children into "normal majority" and "abnormal minority". That is why the issue of socialization of preschool children with special needs becomes more and more important. The review of some scientific works has shown that the issue of forming mechanisms of interaction between the teachers of special educational institutions and their students towards improving the efficiency of their socialization is still understudied. The paper is aimed at the formation of interaction model between special educational institutions teachers and their students towards increasing the efficiency of their socialization. The further education of children with special needs will be easier if their socialization and social adaptation in the social environment begin in the preschool age. Under these conditions their future life and professional activities will be more socially adapted. The developed model makes it possible to perform such tasks of socialization of children with special needs: acquisition of abilities and skills needed for normal functioning of these children in the society; forming adequate social behavior, social "self"; mastering the norms of culture, etc.

Keywords: special education, inclusive education, socialization, children with special needs, psychophysical disturbances, social adaptation, preschool education.

\section{Introduction}

Modern social relations in our country are far from being harmonious. As to educational system, such disharmony is even stronger, because it is expressed in separating of mass and correctional education. Attempts to form inclusive education have not come to any considerable results, which appears in constant division of children into "normal majority" and "abnormal minority". That is why the issue of socialization of preschool children with special needs is of specific importance.
In the process of literature review, three groups of scientists, whose works were of interest in the context of this study, were distinguished. Firstly, works that concern socialization as a phenomenon and a process were studied. In this regard, thoughts of G. Andreeva, E. Andrienko, S. Litvinenko, B. Lomov, M. Lukashevych, V. Moskalenko, S. Savchenko, T. Semygina appeared to be interesting. Secondly, views of scholars on the peculiarities of socialization of children of preschool age were considered (A. Mudryk, V. Mukhina, A. Kapska, T. Kravchenko, I. Rogalska). Thirdly, scholars V. Arbe- 
nina, L. Sokuryanska, L. Khyzhnyak investigated the peculiarities of socialization of children with special needs.

At the same time, in our opinion, the issues of forming mechanisms of interaction between special educational institutions teachers and their students towards increasing of socialization efficiency of these children are still understudied.

The present paper is aimed at presenting the developed interaction model between special educational institutions teachers and their students towards increasing the efficiency of their socialization.

Regarding the aim, the following objectives of the research are distinguished:

- considering the notion about the nature of the category of socialization; children;

- studying socialization peculiarities of preschool

- investigating the principles of special educational institutions functioning;

- presenting the model of interaction between teachers and students of special educational institutions for their successful socialization.

The following methods of scientific research were used: analysis, synthesis, generalization, systematization.

\section{Discussion}

Before discussing the mechanisms of socialization of children with special needs, we should consider the essence of the concept "socialization", because there is no common view of its definition.

In the most general understanding, socialization is considered as "the process of mastering social standards of behavior, values, harmonizing relations with social environment and active reproduction of social experience" [1].

According to some scholars (O. Avramenko, B. Parygin, I. Kon) socialization is a way to ensure the entry of an individual into social communities, comfortable coexistence with other parties in them, the socialization of his/her activities, lifestyles, opinions, encouraging $\mathrm{him} / \mathrm{her}$ to achieve common interests. As a result of the socialization the formation of an individual as a member of certain social groups and communities is provided.

Moreover, many researchers are focused on the process of gaining social experience by an individual, recognizing social values and norms $[4$, p. $344 ; 5$, p. $52 ; 6$, p.176]. In particular, G. Andreeva considers socialization as a two-way process: on the one hand, it is the assimilation of social experience by an individual based on his/her entry into the social environment with the relevant social relations, and on the other hand, it is the process of active reproduction of social relations by an individual based on his/her activities as a member of the society [6, p.176].

It is this interpretation of socialization that can be considered the most common and acceptable because it identifies the interaction of the individual and the society.

Ye. Andrienko also understands socialization as one that is twofold and is the interaction of internal and exter- nal content. At that the internal content of socialization is a process of forming of the holistic personality, and external content is a complex of all social impacts on an individual [11]. Such dual understanding of the nature of socialization is found also in the works of B. Lomov [7], M. Lukashevich and T. Semigina [8].

According to Russian researcher A. Mudryk, socialization is the process of the individual's development in interaction with the environment $[5$, p. 52]. However, the author identifies the following types of socialization: spontaneous (in the process of spontaneous interaction between an individual and the society), relatively guided (as a result of the state's impact on the process of socialization), relatively controlled (in the process of planned creating of conditions for the development of a person by the society and the state), conscious self-transformation of an individual (to greater or less extent).

We agree with the opinion of A. Kapska that socialization is a process of consistent entry of an individual into the social environment, accompanied by assimilation and reproduction of society's culture in the process of its interaction with living conditions [9]. Besides, we share the idea of S. Savchenko that socialization should be considered as a multi-aspect process of acquiring human qualities which can form behavior in a particular social situation, provide subject-subjective unity of personality, and also acquisition and reproduction of social values and norms by an individual $[10$, p. 61]. V. Moskalenko states that socialization is a process in which an individual is a prerequisite of social development and at the same its result; the process which expresses the objective-subjective unity of the internal, natural and social [12, p.194].

Also we agree with the opinion of S. Litvinenko that a person is as socially successful as he/she is socially adaptive. Thus, a man becomes the subject of social development remaining the subject of self-development [13, pp. 216-219].

It should be mentioned that as early as in 80 s of the twentieth century the process of socialization was considered by both researchers in the field of sociology and psychology. In the 90s, the new paradigm of education was formed. It was based on humanization and democratization of the educational process, formation of human values and norms of behavior in the society. These processes, in turn, are supported by the strengthening of the role of national education.

According to A. Kapska, the main socio-educational factor of socialization in the process of implementing educational objectives is traditional socialization mechanism, which is associated with the assimilation of norms and standards of behavior by a child, as well as attitudes and stereotypes specific to his/her family and the closest environment as they are absorbed in unconscious or subconscious level [9].

A. Mudryk notes that when investigating the socialization of preschool children one should be focused on the processes of personality's formation, as they determine their development due to specific social conditions [5, p. 50]. 
V. Mukhina considers socialization of children as their development based on the dialectical unity of the internal conditions and the internal position, which results in their acquisition of the social environment through the aspiration to fulfill the desire for recognition [14, p.71].

In turn, T. Kravchenko identifies the following main characteristics of the socialization process of children: adaptation (adjustment to the social environment of a child and the partial adaptation of the environment to a child); social role (behavior pattern that is determined by the social position of a child in the system of social or interpersonal relations); social status (regulated behavior pattern in the society that is supported by respective rights and obligations); social norms (rules of conducting in the society); moral norms (moral requirements to behavior); social instructions (focus on social values); social behavior (regulated by an individual and social consciousness, by social institutions, legal norms, etc.); values (appreciated by a child); value orientations (conscious social values that meet the needs of a child); social consciousness (reflection of social reality); social experience (the result of the previous development of the society); social relations (between representatives of certain social groups); factors of socialization (conditions which influence a child in the process of his/her integrating into the society); socialization agents (the persons who set certain parameters to the child's value orientations); ways of socialization (specific types of the child's interactions with the environment) [15, p. 13]. The author reasonably substantiated a close relationship between education of a child and his/her future socialization in the context of activity and synergistic approaches.

An important contribution to the study of the nature of the socialization process of preschool children was made by I. Rohalska, who defines it as a process of the formation of a child's personality in his/her interaction with the social world by entering into the system of social relations, the assimilation of socio-cultural experience through subjective knowledge of the surrounding world and the construction of the image of the social world [16, p.17].

The specificity of a preschool child's socialization, according to the author, involves the continuous changing of the "social maturation"; ensuring the expansion of the freedom degree in the process of entering the society; development of the subjective activity; formation of social competence; social and emotional development of the society [16, p. 26].

Considering the socialization of preschool children with special needs in the light of special (correctional) education, it should be noted they require a different approach to this process. Nowadays these children are mostly associated with special educational institutions, which are isolated from the society. The process of the development of inclusive education, due to which such children are able to attend ordinary secondary schools, is very slow. As for the early childhood (pre-school period) these children in most cases stay in the specialized educational institutions.

As it was noted earlier [17], the positive aspect of integration of general and special (correctional) education was the adoption of the Concept of inclusive education. In a memorandum to the Concept there is the following statement: "By joining to the major of international treaties on human rights (UN Declaration about Human Rights, UN Conventions about the Rights of the persons with disabilities, the rights of the child), Ukraine has committed itself to respect human rights, in particular, to ensure the right for education of children with special educational needs".

Taking into account the aspects outlined in these regulations, we have distinguished the following tasks of special educational institutions (SEI) in Ukraine [17, pp.49-50]:

1) forming necessary conditions for the development of an individual using his/her potential;

2) providing essential and methodical sequence at different stages of studying;

3) providing the development of mental functions, sensor systems of preservation and strengthening of children's health;

4) forming different training variants within preschool, primary, basic and secondary schools for children of different categories depending on their potential educational capabilities;

5) substantiating the content of public, correctional and school components of the basic curriculum of different types of special educational institutions;

6) determining means of socialization and adaptation of children, the basic principles of correctional education, the content of special teaching technologies;

7) forming the institution of the family, providing assistance and support to parents in the upbringing of children.

The social nature of the specified tasks is that their implementation contributes to the potential adaptation and socialization of children with special needs in the surrounding social environment, forms a complex interaction of the state, education, family and the society in this direction. In particular, we believe that further education of children with special needs is the least vulnerable if their socialization and social adaptation in the environment of healthy children take place at school (for example in the form of inclusive education). Under such conditions their student life and further professional activities will also be more socially adapted. In addition, the study of the behavior of students made by B. Arbienina and L. Sokuranska proves its greater tolerance compared to other age periods [18, pp. 402-432].

Moreover, globalization processes occurring today in the national educational system on the way to European integration, which was emphasized by L. Khyzhniak, also promote the socialization and social adaptation of these children [19].

Thus, the changes which are implemented into the national standards of special education contribute to over- 
coming stereotypes in understanding of socialization of children with special needs. The basic idea of this education is revaluation of compensatory correctional load, purposeful development of psycho-physiological processes that help to improve the level of acquisition of knowledge and skills by a child and his/her integration into the society. Special education acquires a new status and move to a new stage of the development in general secondary education in the context of recent educational standards.

One should not forget that the correction is the basis of special educational system, which includes compensation as an internal process of changing the lost functions and rehabilitation as a process and a result of renovation of functions and psychophysical development of children with special needs.

We defined training, education, correction and development as the components of special education [20]. However, correction is considered as the basis of education in a special school. The effectiveness of training and education of a child reduces, the process of mastering of the necessary knowledge, skills, development of his/her behavior, as well as socialization and integration into the society are complicated without the purposeful overcoming or weakening of the disadvantages of the child's development.

A key feature of special educational institutions, compared to traditional ones, is the presence of correctional and developmental aspects that were proved by us in the earlier works [20]. It is the object of correction (that needs to be corrected and developed in a child) which the content of the educational component depends on. The less correctional influence is required, the more working plans of the educational process of special educational institutions are close to the secondary school curriculum.

Thus, the correctional and developmental work is considered by us as a basis of the educational process in special educational institutions, which is carried out on the one hand, by the methods of the traditional educational process and on the other hand - the required level of correctional and supporting efforts in the process of bringing up the abnormal children's development to the normal level. In our view, in the process of current development of special education its social dimension cannot be seen, namely: organization of a favorable social environment for the implementation of the main tasks of correctional education - adaptation and socialization of children with special needs.

It should be also noted that the result of socialization is a social type of person with a set of social personality traits manifested in his/her mind and behavior.

A child with special needs is perceived ambiguously by different members of the society. Unfortunately, not all people perceive this child in an adequate way. As a result, the child's relations with the community in many cases develop inadequately; he/she becomes unsociable and does not want to communicate with others. Even in adulthood, such a person will have a lot of complexes and obstacles on his/her way to becoming a full member of the society. Therefore, in this case the effective interaction of an employee and a student of a special educational institution on the way to overcoming of social and personal obstacles to complete social adaptation and socialization is considered to be very important.

Subject-subject relations open up much more opportunities for getting certain social results of SEI workers, especially in preschool. Focusing on the child as a subject with a certain social status makes it possible to observe his/her interaction with other members of the society both within the SEI and beyond, more meaningfully evaluate the possible social result of these professional activities. It is not for nothing; due to this approach it is possible to reconsider the formation of "sociality" of the child, namely to regard it as a proactive, responsive and effective process. The formation of personal qualities of the child is carried out not in isolation (as a part of his/her development) but in the interaction with the social environment.

It is assumed that the use of subjective factors of interaction causes the significant change of the development and transformation of social processes, including social interaction. Indeed, the essence of the processes of socialization and social adaptation is manifested through different kinds of relationships. The ability of a person to be engaged and participate in the process of building different relationships with others embodies the subjective dimension of the socialization process. This is confirmed by some researchers who believe that the category of a subject appears where there is a need for study of person's interaction with the world, coordination and comparison of his/her abilities and values with external conditions and circumstances of the reality [21, p.7; 22, p.26].

Only a subject (as distinct from the object) combines two planes of reality - individual and social. A person provides his/her interaction with the reality in various forms of activities (activity, cognition, communication), forming situational or prolonged bonds between these forms; interacts with the world in different dimensions, through the complex of which follows his/her life path.

Besides, the indicators of so-called social subjectivity are highlighted in the research studies of L. Sokurians$\mathrm{ka}$, including individual psychological readiness for selfemployment, theoretical and practical preparedness for it, responsibility for the results, willingness to take risks, the ability to influence other people [23, p.7]. This fact once again confirms the importance of subject-subject interaction in the implementation of social relations.

Thus, the subjective nature of SEI students' socialization is manifested in the moments of coordination of individual peculiarities of functioning with the external conditions and factors of social coexistence. Therefore, in our opinion, the relations of workers and SEI students have the strongly pronounced subject-subjective nature, which definitely improves their social interaction: firstly, the processes of social adaptation and socialization are manifested more actively and more completely; secondly, there is a category of social efficiency, which cannot exist 
in the subject-object relations (Fig. 1).

Consequently, the subjectivity factor in the interaction of a teacher and SIE students plays an important role in the improvement of the quality of social adaptation processes and socialization of these children.

\section{Conclusions}

Thus, the essence of socialization of preschool children with special needs can be defined as the process of their entering the system of social relations, the result of their development as the future universal subjects of activity through their multileveled interaction with the society.

We distinguish the following peculiarities of socialization of preschoolers with special needs:

- acquiring qualities needed for life and acting in the society, engaging in social relations, formation of social roles, etc;

- forming conditions for the efficient psychical, physical and mental development of the child, his/her formation as "a person among people";

- implementing multifaceted self-governing of social behavior of a child;

- mastering the elements of human culture, social norms and laws;

- influencing the child by different means of educational activities through the formation of social "self";

- eliminating the undesired socialization results under certain educational conditions (antisocial behavior, alienation).

Our further research is aimed at comparative studying of the efficiency of socialization of children with special needs in terms of special and inclusive education.

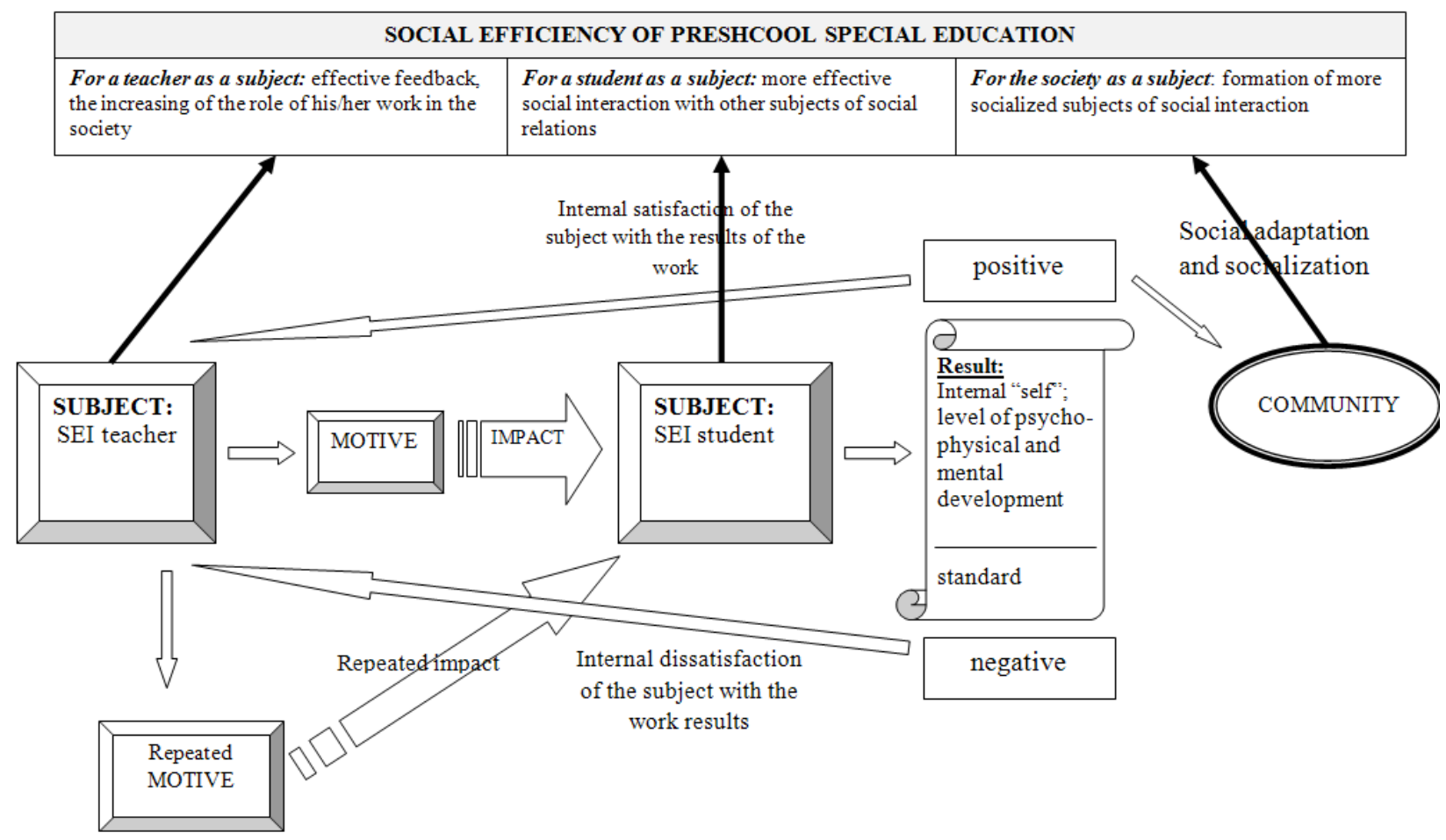

Fig. 1. Model of subject-subject interaction between a teacher and SEI students (the author's approach)

\section{REFERENCES}

1. Avramenko, O. O. (2013). Socializatsiia osobystosti yak sotsialno-pedahohichna problema [Socialization of the person as a socio-pedagogical issue]. Visnyk Natsionalnoi akademii Derzhavnoi prykordonnoi sluzhby Ukrainy. Seriia: Pedahohichni nauky - Bulletin of National Academy of State Border Force. Series: Education, 5. Retrieved from: http://www.irbis-nbuv.gov.ua/cgibin/irbis_nbuv/cgiirbis_64.exe?I21DBN=LINK\&P21DB $\mathrm{N}=\mathrm{UJRN} \& Z 21 \mathrm{ID}=\& \mathrm{~S} 21 \mathrm{REF}=10 \& \mathrm{~S} 21 \mathrm{CNR}=20 \& \mathrm{~S} 21 \mathrm{ST}$ $\mathrm{N}=1 \& \mathrm{~S} 21 \mathrm{FMT}=\mathrm{ASP}$ meta\&C21COM=S\&2 S21P03=FI $\mathrm{LA}=\& 2 \_\mathrm{S} 21 \mathrm{STR}=\mathrm{Vnadps} \_2013 \_5$ 3 [in Ukrainian].

2. Parygin, B. D. (1971) Osnovy sotsialnopsikhologicheskoy teorii [Fundamentals of social and psychological theory]. Moscow: Mysl [in Russian].
3. Kon, I. S. (2003). Rebenok i obshchestvo [The child and society]. Moscow: Izdatelskiy tsentr "Akademiya" [in Russian].

4. Levada, Yu. A. (1970). Sobranie sochineniy [Complete Works]. Moscow: Nauka [in Russian].

5. Mudrik, A. V. (2005) Sotsializatsiya cheloveka kak problema [The socialization of the person as a problem]. Sotsialnaya pedagogika - Social education, 4, 4757 [in Russian].

6. Andreeva, G. M. (1996). Sotsialnaya psikhologiya [Social Psychology]. Moscow: Aspekt-Press [in Russian].

7. Lomov, B. F. (1984). Metodologicheskie $i$ teoreticheskie problemy $v$ psikhologii [Methodological 
and theoretical problems of psychology]. Moscow: Nauka [in Russian].

8. Lukashevych, M. P., \& Semyghina, T. V. (2007). Sotsialna robota (teoriia i praktyka) [Social work (theory and practice)]. Kyiv: IPK DSZU [in Ukrainian].

9. Kapskaya, A. (Ed.). (2003). Sotsialna pedahohika [Social education]. Kyiv: Centr navchalnoi literatury [in Ukrainian].

10. Savchenko, S. V. (2004). Naukovo-teoretychni zasady sotsializatsii studentskoi molodi v pozanavchalnii diialnosti $\mathrm{v}$ umovakh reghionalnoho prostoru [Scientific and theoretical basis of socialization of students in extracurricular activity in conditions of the regional space]. Extended abstract of Doctor's thesis. Luhansk: Lugansk National Pedagogical University named after T. G. Shevchenko [in Ukrainian].

11. Andrienko, E. V. (2002). Sotsialnaya psikhologiya [Social Psychology]. Moscow: Akademiya [in Russian].

12. Moskalenko, V. V. (1986). Sotsializatsiya lichnosti [Socialization of personality]. Kyiv: Vishcha shkola [in Ukrainian].

13. Lytvynenko, S. Ya., \& Jamnyskyi, V. M. (2002). Dytyna i seredovyshhe: problemy vzaiemodii [Child and environment: problems of interaction]. Onovlennia zmistu ta metodiv navchannia $i$ vykhovannia $v$ zakladakh osvity - Updating of the content and methods of training and education in educational institutions, 22, 216-219 [in Ukrainian].

14. Mukhina, V. S. Vozrastnaya psikhologiya [Agerelated psychology]. Moscow: Akademiya [in Russian].

15. Kravchenko, T. V. (2010). Teoretykometodychni zasady sotsializatsii ditei shkilnoho viku $u$ vzaiemodii simii i shkoly [Theoretical and methodological principles of socialization of children of school age in the interaction of family and school]. Extended abstract of Doctor's thesis. Kyiv: Institute of Educational Problems of National Academy of Pedagogical Sciences of Ukraine [in Ukrainian].

16. Rohalska, I. P. (2009). Teoretyko-metodychni zasady sotsializatsii osobystosti u doshkilnomu dytynstvi [Theoretical and methodological principles of socialization in early childhood]. Extended abstract of Doctor's thesis. Luhansk: Lugansk National Pedagogical University named after T. G. Shevchenko [in Ukrainian].

\section{ЛIТЕРАТУРА}

1.Авраменко О. О. Соціалізація особистості як соціально-педагогічна проблема / О. О. Авраменко // Вісник Національної академії Державної прикордонної служби України. Серія: Педагогічні науки. Електронне наукове фахове видання. - 2013.- Вип. 5. [Електронний ресурс]. - Режим доступу: http://www.irbis-nbuv.gov.ua/cgiin/irbis_nbuv/cgiirbis_64.exe?I21DBN=LINK\& $\mathrm{P} 21 \mathrm{DBN}=\mathrm{UJRN} \& Z 21 \mathrm{ID}=\& \mathrm{~S} 21 \mathrm{REF}=10 \& \mathrm{~S} 21 \mathrm{CNR}=20 \&$ $\mathrm{S} 21 \mathrm{STN}=1 \& \mathrm{~S} 21 \mathrm{FMT}=\mathrm{ASP}$ meta\&C21COM=S\&2_S 1 $\mathrm{P} 03=\mathrm{FILA}=\& 2 \_S 21 \mathrm{STR}=$ Vnadps_2013_5_3
17. Kolomoiets, T. Gh. (2014). Normatyvne zabezpechennia maibutnioi sotsializatsii ta sotsialnoi adaptatsii vykhovantsiv korektsiinykh zakladiv osvity [Normative maintenance of future socialization and social adaptation of pupils of correctional educational institutions]. Materialy Mizhnarodnoi naukovo-praktychnoi konferentsii «Suspilni nauky, istoriia, suchasnist i maibutnie» - Proceedings of international scientific conference "Social sciences, history, present and future". (pp. 48-51). Kyiv: Kyivska naukova suspilnoznavcha orhanizatsiia [in Ukrainian].

18. Arbienina, V. L. \& Sokuranska, L. Gh. (Ed.). (2012). Ukrainske studentstvo u poshukakh identychnosti : monohrafiia [Ukrainian students in search of identity: monograph]. Kharkiv : Kharkiv National University named after V. N. Karazin [in Ukrainian].

19. Khyzhniak, L. M. (2007). Derzhavna osvitnia polityka $\mathrm{v}$ umovakh hlobalizatsii: poshuky optymalnoi modeli [State educational policy in the context of globalization: the search for the optimal model]. Derzhavne budivnytstvo - State building, 1. Retrieved from: http://www. kbuapa.kharkov.ua/e-book/db/2007-12/index.html [in Ukrainian].

20. Kolomoiets, T. Gh. (2014). Formuvannia systemy spetsialnoi osvity dlia ditei z osoblyvymy potrebamy: sotsiolohichnyi aspekt [Formation of special education for children with special needs: sociological aspect]. Nova paradyhma - New paradigm, 123, 195-205 [in Ukrainian].

21. Abulkhanova, K. A. \& Slavskaya, A. N. (2003). Predislovie. Bytie $i$ soznanie. Chelovek $i$ mir. / S. L. Rubinshteyn [Preface. Being and consciousness. Man and the world / S. L Rubinstein]. Moscow: Mysl [in Russian].

22. Barabanshchikov, V. A. (Ed.). (2005). Ideya sistemnosti $v$ sovremennoy psikhologii [The idea of the system character in modern psychology]. Moscow: In- psikhologi RAN [in Russian].

23. Sokuranska, L. Gh. (2007). Tsinnisna determinatsiia stanovlennia sotsialnoi subiektnosti studentstva v umovakh sotsiokulturnoi transformatsii [Determination of values of social subjectivity formation of students in terms of sociocultural transformation]. Extended abstract of Doctor's thesis. Kharkiv: Lugansk National Pedagogical University named after T. G. Shevchenko [in Ukrainian].

2.Парыгин Б. Д. Основы социальнопсихологической теории / Б. Д. Парыгин. - М. : Мысль, 1971. - 351 с.

3.Кон И. С. Ребенок и общество : учеб. пособие для студ. высш. учеб. заведений / И. С. Кон. - М. : Издательский центр «Академия», 2003. - 336 с.

4. Левада Ю. А. Собрание сочинений / Ю. А. Левада. - Москва : Наука, 1970. - 344 с.

5. Мудрик А. В. Социализация человека как проблема / Анатолий Мудрик // Социальная педагогика. 2005. - № 4. - С. 47-57. 
6.Андреева Г. М. Социальная психология / Г. М. Андреева. - Москва. : Аспект-Пресс, 1996. - 376 c.

7.Ломов Б. Ф. Методологические и теоретические проблемы в психологии / Б. Ф. Ломов. - Москва : Наука, 1984. - 446 с.

8. Лукашевич М. П. Соціальна робота (теорія i практика) : навч. посіб. / М. П. Лукашевич, Т. В. Семигіна. - Київ : ІПК ДСЗУ, 2007. - 341 с.

9.Соціальна педагогіка : підручник / за ред. А. Капської. - Київ : Центр навчальної літератури, 2003. $-256 \mathrm{c}$.

10. Савченко С. В. Науково-теоретичні засади соціалізації студентської молоді в позанавчальній діяльності в умовах регіонального простору : автореф. дис. на здобуття наук. ступеня д-ра пед. наук : спец. 13.00.05 «Соціальна педагогіка» / С. В. Савченко. Луганськ, Луганський національний педагогічний унт ім. Тараса Шевченка. 2004. - 61 с.

11. Андриенко Е.В. Социальная психология. М.: Академия, 2002. - 264 с.

12. Москаленко В.В. Социализация личности. Киев : Вища школа, 1986. - 200 с.

13. Литвиненко С. Я. Дитина і середовище: проблеми взаємодії / С. Я. Литвиненко, В. М. Ямницький // Оновлення змісту та методів навчання і виховання в закладах освіти : зб. наук. праць. - Рівне : РДГУ, 2002. - Вип. 22. - С. 216-219.

14. Мухина В. С. Возрастная психология : учеб. для студ. высш. учеб. заведений / В. С. Мухина. Москва : Академия, 1997. - 432 с.

15. Кравченко Т. В. Теоретико-методичні засади соціалізації дітей шкільного віку у взаємодії сім'ї і школи : автореф. дис. на здобуття наук. ступеня д-ра пед. наук : спец. 13.00.07 «Теорія і методика виховання» / Т. В. Кравченко. - Київ : Інститут проблем виховання Національної академії педагогічних наук України, 2010. - 40 с.

16. Рогальська I. П. Теоретико-методичні засади соціалізації особистості у дошкільному дитинстві : автореф. дис. на здобуття наук. ступеня д-ра пед. наук : спец. 13.00.05 «Соціальна педагогіка» / І. П. Рогальська. - Луганськ, 2009. - 43 с.

17. Коломоєць Т. Г. Нормативне забезпечення майбутньої соціалізації та соціальної адаптації вихованців корекційних закладів освіти / Т. Г. Коломоєць // Суспільні науки, історія, сучасність і майбутнє : матер. Міжнародної науково-практичної конференції, 5-6 вересня 2014 р. - Київ. : Київська наукова суспільнознавча організація, 2014. - С. 48-51.

18. Українське студентство у пошуках ідентичності : монографія / [за ред. В. Л. Арбєніної, Л. Г. Сокурянської]. - Харків : ХНУ імені В. Н. Каразіна, 2012. - 520 с.

19. Хижняк Л. М. Державна освітня політика в умовах глобалізації: пошуки оптимальної моделі / Л. М Хижняк // Державне будівництво. - 2007. - № 1. - [Електронний ресурс] - Режим доступу: http://www.kbuapa.kharkov.ua/e-book/db/2007-1-

2/index.html

20. Коломоєць Т. Г. Формування системи спеціальної освіти для дітей з особливими потребами: соціологічний аспект / Т. Г. Коломоєць // Нова парадигма. - 2014. - № 123. - С. 195-205.

21. Абульханова К. А. Предисловие / К. А. Абульханова, А. Н. Славская // Бытие и сознание. Человек и мир / С. Л. Рубинштейн. - Москва : Мысль, 2003. - С. 6-33.

22. Идея системности в современной психологии / [под ред. В. А. Барабанщикова]. - Москва : Ин-т психологи РАН, 2005. - 496 с.

23. Сокурянська Л. Г. Ціннісна детермінація становлення соціальної суб'єктності студентства в умовах соціокультурної трансформації : автореф. дис. на здобуття наук. ступеня д-ра соціол. наук : спец. 22.00.04 «Спеціальні та галузеві соціології» / Людмила Георгіївна Сокурянська ; Харк. нац. ун-т ім. В.Н. Каразіна. - Харків, 2007. - 36 с.

Таміла Григорівна Коломосцьь, кандидат соиіологічних наук, стариий викладач, Криворізький державний педагогічний університет, пр. Гагаріна, 54, м. Кривий ріг, Украӥна

\section{МОДЕЛЬ СОЦІАЛІЗАЦІЇ ДОШКІЛЬНИКІВ 3 ОСОБЛИВИМИ ПОТРЕБАМИ В СИСТЕМІ СПЕЦАЛЬНОЇ ОСВІТИ}

Сучасні соціальні відносини у нашій країні далекі від гармонійних і вимагають істотних змін. Особлива увага необхідна неповносправним дітям, які потребують від освітніх закладів якісної освіти і допомоги. Тому проблема соціалізації дітей з особливими потребами ще з дошкільного віку виходить на новий рівень актуальності. Аналіз існуючих наукових праць показав, що невирішеними залишаються питання формування механізму взаємодії вихователів спеціальних закладів освіти і їх вихованців у напрямку підвищення ефективності соціалізації останніх. Метою дослідження є формування моделі взаємодії вихователів спеціальних закладів освіти з їх вихованцями у напрямку підвищення ефективності соціалізації дітей з особливими потребами. Результати дослідження полягають в наступному: доведена актуальність соціалізації дітей з особливими потребами ще у дошкільному віці; здійснено критичний аналіз наукових праць 3 питань соціалізації; вказано на відсутність єдиної думки у тлумаченні цього поняття; узагальнено основні наукові погляди 3 цього питання; сформовано основні задачі спеціальних закладів освіти, які дозволять поліпшити процес соціалізації дітей з особливими потребами; доведено суб'єктно-суб'єктний характер взає- 
мин працівника спеціального закладу освіти з його вихованцями; побудовано модель такої взаємодії. Можна вважати, що подальший освітній процес неповносправних дітей проходить в менш вразливому вигляді, якщо їхня соціалізація та соціальна адаптація в середовище здорових дітей відбуваються ще під час дошкільного віку. За таких умов їхнє майбутнє життя та подальша професійна діяльність також будуть носити більш соціально адаптований характер. Побудована модель дозволяє реалізувати такі напрями соціалізації дітей з особливими потребами: набуття дитиною якостей для життя і діяльності в суспільстві; формування самокерованої соціальної поведінки дитини, соціального «Я»; оволодіння елементами людської культури, соціальними нормами та законами; отримання результатів соціалізації в певних навчально-виховних умовах, які виключають небажані результати (асоціальна поведінка, відчуження особистості від соціуму).

Ключові слова: корекційна освіта, інклюзивна освіта, соціалізація, діти з особливими потребами, психосоціальні порушення, соціальна адаптація, дошкільна освіта.

Submitted on February, 13, 2017

Reviewed by Doctor of Pedagogy O. Kovshar

УДК: $821.161 .2(07)$

DOI: https://doi.org/10.24195/2414-4665-2017-2-10

Ірина Анатолївна Кучеренко,

доктор педагогічних наук, дочент,

професор кафедри практичного мовознавства,

Уманський державний педагогічний університет імені Павла Тичини, вул. Садова, 2, м. Умань, Украӥна

\section{ВИВЧЕННЯ УКРАЇНСЬКОЇ МОВИ В АСПЕКТІ ОСОБИСТІСНО ЗОРІЕНТОВАНОЇ ТЕХНОЛОГІЇ НАВЧАННЯ}

Сучасна мовна освіта в Україні, спрямована на формування мовної особистості, передбачає пошук продуктивних освітніх технологій, розроблення ефективних иляхів організації навчального процесу. Особистісно зорієнтована технологія навчання украӥнської мови є однією з перспективних технологій, щуо забезпечує оптимальні й ефективні умови для гармонійного розвитку комунікативної компетентності кожного учня. Мета дослідження полягає в обтрунтуванні особливостей особистісно зорієнтованого навчання украӥнської мови, характеристиці иляхів упровадження особистісно зорієнтованої технологї̈ навчання, розробленні технологічної моделі особистісно зорієнтованого уроку украйнської мови. У результаті проведення наукової розвідки було уточнено концепиію й особливості особистісно зорієнтованої технології навчання української мови, визначено шляхи імплементації означеної технології у практику мовного навчання. Представлено розроблену технологічну модель особистісно зоріснтованого уроку української мови, щуо включає основні структурні етапи заняття (мотивація, цілевизначення, реалізація, рефлексія, контроль, корекція навчання), проаналізовано їх процесуальні та змістові особливості. Визначено головні аспекти структури особистісно зорієнтованих ситуацій, основні їх характеристики та види. Доведено, щзо розроблена особистісно зоріснтована технологія уроку украӥнської мови сприятиме розвитку мовної особистості кожного учня, виробленню власної комунікативної компетентності як здатності індивіда успішно розв'язувати практичні проблеми, ефективно діяти у різних життєвих ситуаціях спілкування.

Ключові слова: особистісно зорієнтоване навчання, особистісно зорієнтована технологія, технологічна модель особистісно зорієнтованого уроку украӥнської мови, мотивація, цілевизначення, реалізація, рефлексія, контроль; корекція навчання особистісно зорієнтовані ситуації.

Постановка проблеми. Зміст сучасної мовної освіти в Україні спрямований на створення оптимальних умов підвищення ефективності навчальновиховного процесу задля формування освіченої, креативної, самодостатньої, духовно багатої мовної особистості учня, розвитку його природних здібностей, реалізації власного пізнавально-творчого потенціалу. Національна доктрина розвитку освіти, Концепція мовної освіти в Україні, Державний стандарт базової і повної середньої освіти утверджують ідею компетентнісно спрямованого й особистісно зорієнтованого навчання, скеровують освітні програми на формування успішного учня, комунікативно компетентного і здатного до ефективних дій у різних сферах життя. Однією з перспективних технологій, що забезпечує ефективність навчального процесу з метою досягнення означених цілей мовного навчання, $\epsilon$ технологія 